\title{
Mycobacterium fortuitum in abscesses of man
}

\author{
A. BECK \\ From the Department of Pathology, Paddington General Hospital, London
}

SYNOPSIS Myco. fortuitum was isolated from subcutaneous abscesses of two patients who had been inoculated with B.C.G. and one patient who had iron injections. The organisms were resistant to a wide range of anti-tuberculous drugs. They were highly virulent for mice in which they produced symptoms of spinning disease. It is thought that the infections originated from contamination of syringes or skin.

Mycobacterium fortuitum was first described in 1938 by Costa Cruz who isolated it from the pus of an abscess in a woman who had received injections of a vitamin preparation. It did not attract much attention in human pathology until the last decade when further reports appeared of its occurrence in abscesses (Wells, Agius, and Smith, 1955; Limbos, Bretey, Jadin, and Brutsaert, 1961; Vandepitte, Desmyter, Brochier, and Gatti, 1962) and in sputum of man (Kushner, McMillan, and Sanderi, 1957; Corpe, Smith, and Stergus, 1961; Hartwig, Cacciatore, and Dunbar, 1962; Dross, Abbatiello, Jenney, and Cohen, 1964). All these isolations were from patients living outside Britain; it is thought that the following three cases of abscesses caused by this bacterium are the first to be reported of patients living in Britain. Two of these followed B.C.G. inoculation and one developed at the site of previous iron injections.

\section{CASE REPORTS}

CASE 1 C.U., a Nigerian teacher aged 33, was inoculated with B.C.G. in Lagos shortly before leaving for Britain. A few days later he developed a painful swelling of his arm near the injection site. When seen two months later at a chest clinic in this country he was found to have a fluctuant swelling of about $1 \frac{1}{2}$ in. diameter near the site of his B.C.G. inoculation. The inoculation site showed only a small papule. The axillary glands were not enlarged and a chest radiograph was normal. The Mantoux test which had been negative before his inoculation was now positive with old tuberculin 1:1000.

Aspiration of the swelling produced thin pus in which atypical acid-fast bacilli were seen. A blood agar culture of pus remained sterile but a Lowenstein culture after six days showed growth of a non-pigmented mycobacterium. The abscess was treated by repeated aspirations followed by injections of $0.5 \mathrm{~g}$. streptomycin into the cavity. Two further cultures of the same mycobacterium were ob-

Received for publication 25 November 1964. tained from the aspirate. The abscess ultimately cleared up under this treatment.

CASE 2 J.C., a student almoner aged 23, developed a fluctuant swelling of her arm about 1 in. above the inoculation site three weeks after B.C.G. inoculation. The site itself showed only a small papule. A lymph gland in the posterior cervical triangle was markedly enlarged. Gram and Ziehl-Neelsen films of pus aspirated from the abscess failed to reveal any organisms and cultures on blood agar remained sterile. A Lowenstein culture produced a moderate number of colonies of an acid-fast bacillus which at first was thought to be B.C.G. but was identified on further investigation as Myco. fortuitum.

The patient was treated with isoniazid and paraaminosalicylic acid which were discontinued after five days when the abscess appeared to have dried up, and the patient ceased to attend for further examination.

CASE 3 R.W., a housewife aged 21, developed a swelling in her right buttock following a course of irondextran injections for anaemia of pregnancy. The swelling was aspirated five months later at Mile End Hospital; culture of pus on ordinary media was found to be sterile. The abscess was incised a month later when a Lowenstein culture of pus produced a scanty growth of a nonpigmented mycobacterium. The abscess subsequently became infected with staphylococci but healed ultimately.

The patient's chest radiograph was normal and there was no history of tuberculosis of herself or her family.

\section{BACTERIOLOGICAL INVESTIGATIONS}

The morphological and physiological characteristics and the virulence of the organisms isolated from these patients were examined by the methods already described (Beck, 1959). In addition, they were tested for their acid production from carbohydrates, their utilization of organic acids, and for their sensitivity to dyes following the scheme devised by Gordon and Smith $(1953,1955)$ for the classification of mycobacteria.

They were also tested by the method described by 
Bönicke (1962) for their production of amidases in the short amide series; results were read after four and 20 hours. Niacin production was examined by Medveczky's (1960) benzidine modification of Konno's method (1960).

Sensitivity to chemotherapeutic drugs was tested on Lowenstein media containing the following drug concentrations per millilitre of medium: I.N.H., $0 \cdot 06,0 \cdot 12$, $0 \cdot 25,0 \cdot 5,1,2 \mu \mathrm{g}$. ; streptomycin, 2, 4, 8, 16, $32 \mu$ g.; P.A.S., $0 \cdot 125,0 \cdot 25,0 \cdot 5,1,2 \mu \mathrm{g}$.; cycloserine, 32, 64, 128, 256, $512 \mu \mathrm{g}$.; ethionamide, $10,20,40,80,160 \mu \mathrm{g}$. The results of these tests were expressed as the resistance ratio, i.e., the ratio of the minimal inhibitory concentrations of the test strain and the standard strain H37Rv.

\section{RESULTS}

MORPHOLOGICAL AND CULTURAL APPEARANCE The microscopic appearance of the three cultures was very similar: the organisms were straight rods varying in length from 1.5 to $4.5 \mu$. On isolation they were acid and alcohol fast but their alcohol-fastness was lost after repeated subculturing whereas their acid fastness to $20 \% \mathrm{H}_{2} \mathrm{SO}_{4}$ was retained. They did not form cords. They grew in two days on Lowenstein medium and almost as rapidly on digest agar and blood agar. No pigment was formed after exposure to light. Cultures C.U. and R.W. formed offwhite, smooth, dome-shaped colonies which were easily emulsified. Culture J.C. produced buff, drylooking colonies with irregular outlines which were less easily emulsified.

PHYSIOLOGICAL CHARACTERISTICS Growth characteristics at various temperatures and chemical reactions of the three cultures were uniform, except for differences in the fermentation of inositol (Table I), and conformed with the pattern of reactions described by Gordon and Mihm (1959) as characteristic of Myco. fortuitum. There was less uniformity in the results of the amidase tests (Table II) but none of the strains differed in the results obtained after 20 hours by more than one reaction from the amidase pattern of Myco. fortuitum described by Bönicke (1962).

SENSITIVITY TESTS Tests with anti-tuberculous drugs
TABLE I

GKOWTH AT VARIOUS TEMPERATURES AND CHEMICAL RE ACTIONS OF CULTURES C.U., J.C., AND R.W.

\begin{tabular}{|c|c|c|c|}
\hline & C.U. & J.C. & R.W. \\
\hline Growth at $20^{\circ} \mathrm{C}$. & + & + & + \\
\hline Growth at $37^{\circ} \mathrm{C}$. & + & + & + \\
\hline Growth at $45^{\circ} \mathrm{C}$ & - & - & - \\
\hline Heat resistance $\left(4 \mathrm{hr}\right.$. at $60^{\circ} \mathrm{C}$.) & - & - & - \\
\hline Aryl sulphatase & + & + & + \\
\hline $\begin{array}{l}\text { Catalase (culture containing } 50 \mu \mathrm{g} / \mathrm{ml} \text {. } \\
\text { I.N.H.) }\end{array}$ & & & \\
\hline $\begin{array}{l}\text { I.N.H.) } \\
\text { Neutral red }\end{array}$ & + & + & + \\
\hline $\begin{array}{l}\text { Neutral red } \\
\text { Niacin }\end{array}$ & - & - & - \\
\hline Acid production from: & & & \\
\hline Glucose, mannitol, mannose, trehalose & + & + & + \\
\hline Inositol & + & - & - \\
\hline $\left.\begin{array}{l}\text { Arabinose, dulcitol, erythritol, galac- } \\
\text { tose, lactose, a-methyl D/glucoside, } \\
\text { raffinose, rhamnose, sorbitol, xylose }\end{array}\right\}$ & - & - & - \\
\hline Utilization of: & & & \\
\hline Citrate, malate, lactate, succinate & + & + & + \\
\hline Benzoate, mucate, oxalate & - & - & - \\
\hline Growth on: & & & \\
\hline Malachite green, methyl violet, pyronin & + & + & + \\
\hline
\end{tabular}

showed widespread resistance (Table III): all strains were resistant to I.N.A.H., streptomycio P.A.S., and cycloserine. Cultures C.U. and R.W. were also resistant to ethionamide while culture J.C. was doubtfully resistant to this drug. All strair were resistant to $10 \mu \mathrm{g}$. $/ \mathrm{ml}$. thiosemicarbazone.

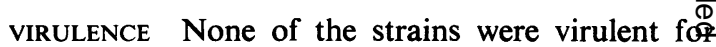

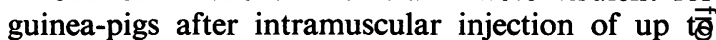
$3 \times 10^{8}$ organisms. Cultures C.U. and R.W. were also tested by intracardiac injection of $5 \times 1 \bar{\theta}^{7}$ organisms into three guinea-pigs each. None ff these animals showed any lesions when killed two to three months later nor did they show any evidence of bacterial multiplication; cultures of lung, splee liver, and kidney remained sterile.

There was, however, marked evidence of virulence in mice injected intravenously. Cultures C.U. ang J.C. killed all mice within two to 23 days when injected intravenously in doses of $5 \times 10^{7}$ organisn into groups of six mice each. The mean surviva time for the two groups was 8.7 and 3.3 days res pectively. With smaller doses of the three cultures

TABLE II

AMIDASE PRODUCTION OF CULTURES C.U., J.C., AND R.W. IN SHORT AMIDE SERIES

\begin{tabular}{|c|c|c|c|c|c|c|}
\hline \multirow[t]{2}{*}{ Substrate } & \multicolumn{2}{|l|}{ C.U. } & \multicolumn{2}{|l|}{$J . C}$. & \multicolumn{2}{|l|}{$R . W$. } \\
\hline & 4 Hours & 20 Hours & 4 Hours & 20 Hours & 4 Hours & 20 Hours \\
\hline Acetamide & + & + & + & + & + & + \\
\hline Benzamide & - & + & - & - & - & - \\
\hline Urea & + & + & + & + & + & + \\
\hline Nicotinamide & - & + & - & + & \pm & + \\
\hline Pyrazinamide & + & + & - & + & - & + \\
\hline Succinamide & - & - & - & - & - & + \\
\hline Allantoin & + & + & - & + & - & + \\
\hline
\end{tabular}


TABLE III

DRUG RESISTANCE RATIOS OF CULTURES C.U., J.C., AND R.W. ${ }^{1}$

\begin{tabular}{llll} 
& $C . U$. & J.C. & $R . W$. \\
\hline I.N.H. & $>2 / 0 \cdot 12$ & $>2 / 0 \cdot 12$ & $>2 / 0 \cdot 12$ \\
Streptomycin & $>32 / 4$ & $>32 / 4$ & $>32 / 4$ \\
P.A.S. & $>2 / 0 \cdot 25$ & $>2 / 0 \cdot 25$ & $>2 / 0 \cdot 25$ \\
Cycloserine & $>512 / 32$ & $>512 / 64$ & $>512 / 32$ \\
Ethionamide & $>160 / 20$ & $160 / 40$ & $>160 / 20$
\end{tabular}

${ }^{1}$ Minimum inhibitory concentration ( $\mu \mathrm{g}$. $/ \mathrm{ml}$.) of test strain

Minimum inhibitory concentration ( $\mu \mathrm{g}$./ml.) of standard strain H37Rv

some animals survived in each group and the mean survival time of those who died was prolonged (Table IV).

A proportion of mice in each group developed spinning disease which is a condition first described by Sabin (1938) and Findlay, Klieneberger, MacCallum, and MacKenzie, (1938) in mice infected with pleuropneumonia-like organisms; it was later found by Levaditi, Vaisman, and Levy, (1949), Penso, Castelnuovo, Gaudiano, Princivalle, Vella, and Zampieri, (1952) and Rees (cited by Gorrill, 1956) in mice infected with mycobacteria and by Gorrill (1952, 1956) in mice infected with $P s$. pyocyanea and Nocardia sebivorans. This condition is characterized by a severe disturbance of the sense of balance. This manifests itself in a tendency for the animal to hold its head to one side and run in a circle in the direction of this turn. The sideward movement of the head may become so intensive that the animal rolls over. If the mouse is suspended by the tail it tends to go into a spin. Symptoms of spinning disease usually appeared 10 to 14 days after infection and persisted until the animal's death. They were often accompanied by marked wasting.

On necropsy the most conspicuous naked-eye lesions were seen in the kidney which contained numerous whitish nodules varying in size from pin-point to $2 \mathrm{~mm}$. diameter (Fig. 1). They were scattered throughout the parenchyma. In animals which survived there was often some puckering and slight shrinking of the kidney. There were no gross naked-eye lesions in other organs except for occasional moderate enlargement of the spleen.

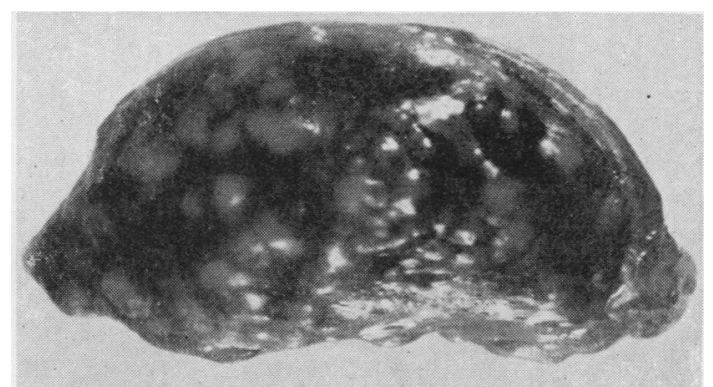

FIG. 1. Multiple abscesses in kidney of mouse injected with culture J.C.

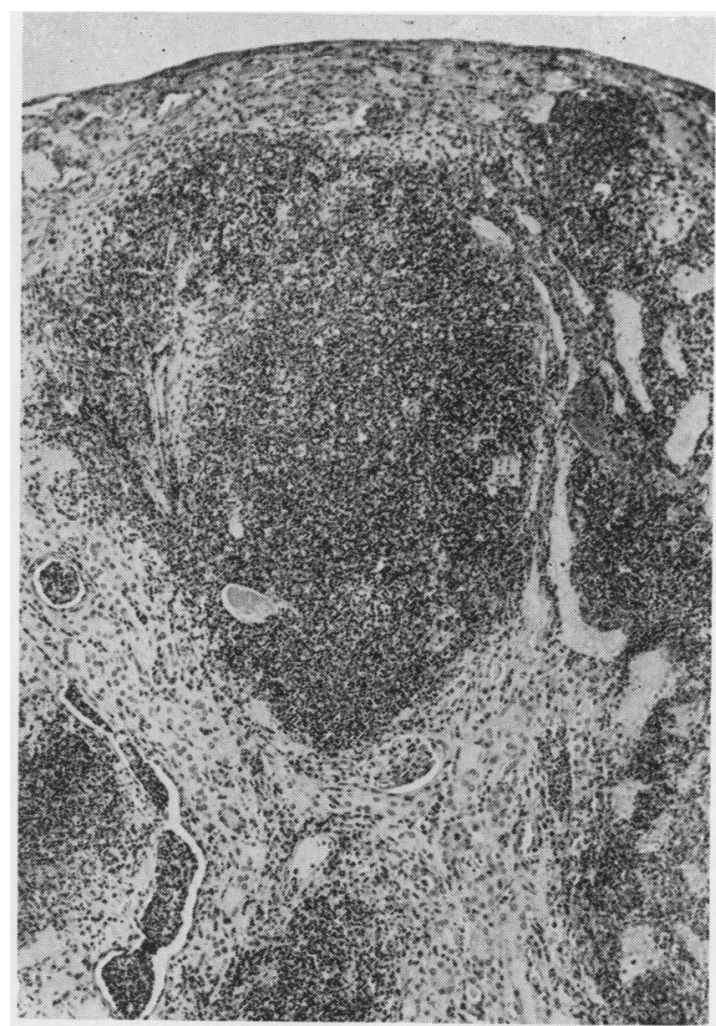

FIG. 2. Abscess of kidney of mouse injected with culture J.C. Haematoxylin and eosin $\times 80$.

\begin{tabular}{|c|c|c|c|c|c|c|}
\hline Culture & $\begin{array}{l}\text { No. of } \\
\text { Organisms } \\
\text { Injected }\end{array}$ & Mortality & $\begin{array}{l}\text { Mean Survival in } \\
\text { Days of Fatal } \\
\text { Cases }\end{array}$ & $\begin{array}{l}\text { Mice Showing } \\
\text { Spinning Disease }\end{array}$ & $\begin{array}{l}\text { Frequency of } \\
\text { Inner Ear } \\
\text { Lesions }\end{array}$ & $\begin{array}{l}\text { Intensity of } \\
\text { Kidney } \\
\text { Lesions }\end{array}$ \\
\hline $\begin{array}{l}\text { C.U. } \\
\text { J.C. } \\
\text { R.W. }\end{array}$ & $\begin{array}{l}1 \times 10^{7} \\
2 \cdot 5 \times 10^{7} \\
1 \times 10^{7}\end{array}$ & $\begin{array}{l}3 / 6 \\
5 / 6 \\
2 / 7\end{array}$ & $\begin{array}{l}29 \\
17 \\
23 \cdot 5\end{array}$ & $\begin{array}{l}2 / 6 \\
3 / 6 \\
2 / 7\end{array}$ & $\begin{array}{l}1 / 1 \\
6 / 6 \\
1 / 1\end{array}$ & $\begin{array}{l}+ \\
+++ \\
++\end{array}$ \\
\hline
\end{tabular}


FIG. 3.

FIG. 5.

FIG. 3. Acid-fast bacilli in abscess of kidney of mouse injected with culture J.C. Ziehl-Neelsen $\times 1,666$.

FIG. 5. Acid-fast bacilli in cochlea of mouse. Ziehl-Neelsen $\times 1,266$.

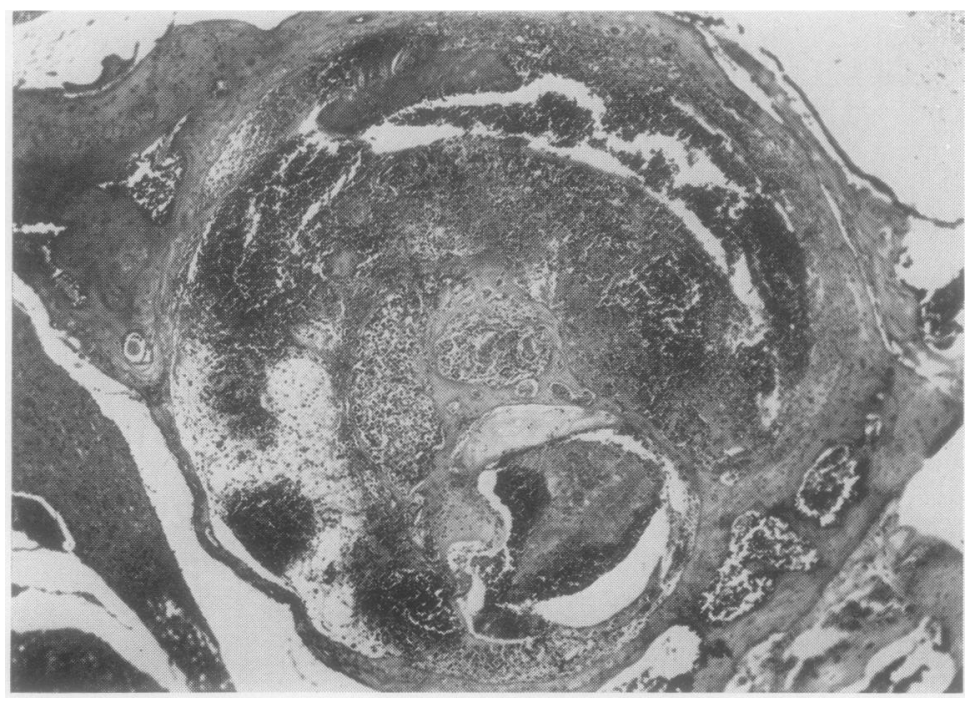

FIG. 4. Destruction of cochlea purulent inflammation; mouse jected with culture J.C. Haem toxylin and eosin $\times 25$. 


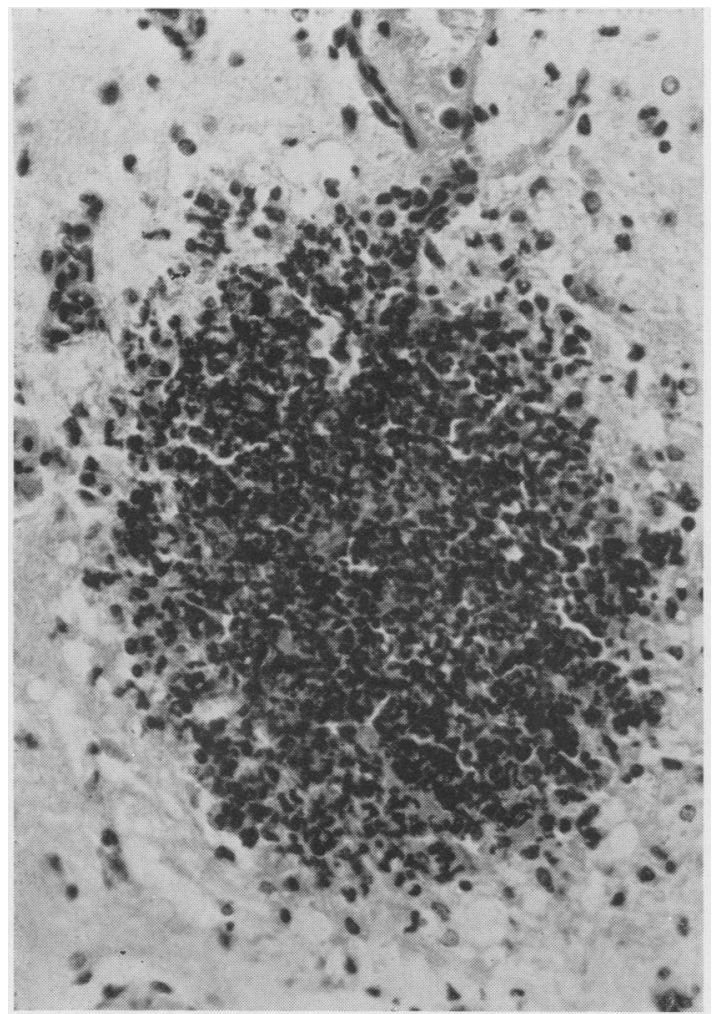

FIG. 6.

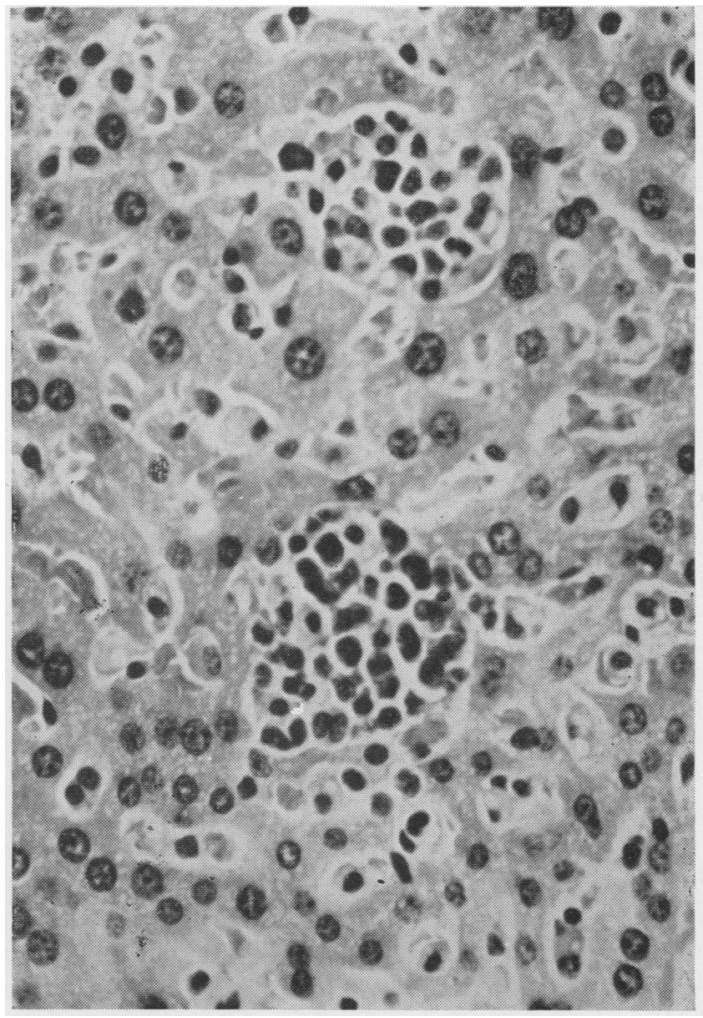

FIG. 7.

FIG. 6. Miliary abscess in brain of mouse injected with culture J.C. Haematoxylin and eosin $\times 266$.

FIG. 7. Inflammatory focus in liver of mouse injected with culture J.C. Haematoxylin and eosin $\times 466$.

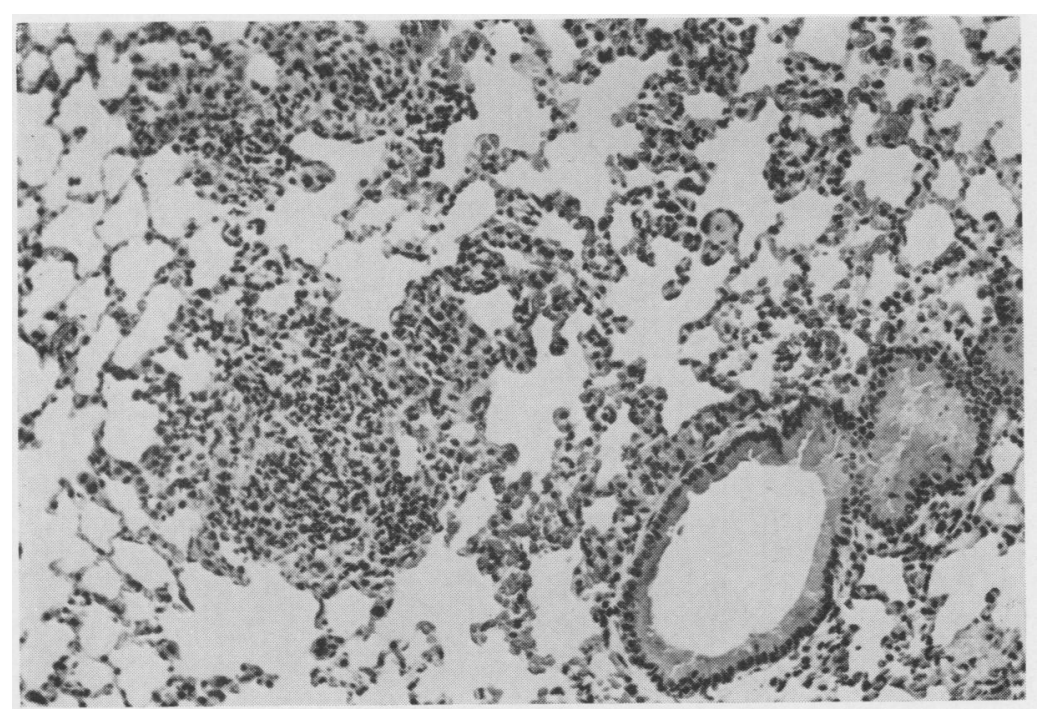

FIG. 8. Granulomatous nodule in lung of mouse injected with culture J.C. Haematoxylin and eosin $\times 146$.

FIG. 8 . 
HISTOLOGY Histological examination revealed numerous, often confluent, abscesses in the cortex and medulla of the kidney (Fig. 2). These were composed of polymorphs and contained masses of acid-fast bacilli which were often packed in tight clusters giving the appearance of a microcolony (Fig. 3). There were accumulations of pus cells in Henle's tubules and occasionally in the pelvis of the kidney. In older lesions polymorphs were replaced by small round cells, and there was increased overgrowth of fibrous tissue.

Cultures of kidney almost invariably produced heavy growth of a mycobacterium identical with the one injected whereas cultures of lung, liver, and spleen yielded only a scanty growth or were negative.

In a group of six mice injected with culture J.C. serial sections of the skulls were prepared through the courtesy of Professor I. Friedmann of the Institute of Laryngology and Otology. These revealed, in the five mice which died, severe purulent inflammation of the inner ear affecting mainly the cochlea (Fig. 4). The pus contained masses of acid-fast bacilli, occasionally in microcolonies similar to those seen in the kidney (Fig. 5). The process was often bilateral and led to the total destruction of this organ. The sixth mouse which survived and was killed two months after injection showed a more chronic unilateral lesion in which the right cochlea was filled with vascular fibrous granulation tissue containing groups of plasma cells. No acid-fast bacilli could be found. Five of the six mice also had multiple miliary abscesses in the brain which were composed of polymorphs and contained acid-fast bacilli (Fig. 6). Similar lesions of the inner ear and brain were also seen in two mice injected with cultures C.U. and R.W., respectively, which had developed spinning disease. However, no systematic investigation was made of the incidence of labyrinthic or cerebral lesions in the groups of mice injected with these two cultures.

Histological examination of the liver revealed numerous small foci of infiltration with small round cells, polymorphs, and endothelial cells in the portal tracts and within the lobules around the sinusoids (Fig. 7). The lung showed scattered miliary nodules composed of endothelial cells, polymorphs, and fibroblasts arising in the interalveolar septa (Fig. 8); the walls of the alveoli surrounding these nodules were thickened by infiltration with similar cells and by congestion. Coalescence of these nodules resulted in larger areas of pulmonary infiltration and congestion. Acid-fast bacilli were scanty or absent in both lung and liver on microscopic and cultural examination. No gross changes were seen in the spleen which on culture was either sterile or yielded only a few colonies of acid-fast bacilli.

\section{DISCUSSION}

The fact that two of the investigated cultures were isolated from abscesses following B.C.G. inoculatiơn raises the question of their possibly being B.C.QS This possibility is ruled out by their fast rate of growth, their ability to multiply almost as well $20^{\circ} \mathrm{C}$. as at $37^{\circ} \mathrm{C}$., their growth on simple media such as digest agar (Therapeutic Substances Regulation\& 1952), and their widespread resistance to antituberculous drugs. On the other hand, the culturaf and physiological characteristics of these organisms agree well with Gordon and Mihm's (1959) descrie tion of Myco. fortuitum. They also share with this organism their high virulence for mice and theit resistance to anti-tuberculous drugs (Penso et a $f_{00}$ 1952; Wells et al., 1955).

There is no definite evidence on the mode of infection in these patients. The fact that it occurre on the site of previous injections is highly suggestive that the organisms entered by this route. There also a theoretical possibility of organisms present other parts of the body being attracted to a locus minoris resistentiae such as exists at the site of ah injection. This is suspected to have been the mech anism of infection in a case reported by Forbes an Strange (1949) where a tuberculous abscess deve oped at the site of a penicillin injection. There however, no evidence that any of the three patien had an infection with Myco. fortuitum in any other site.

Enquiries were made at Lagos where the firsh patient had been vaccinated with B.C.G. Althoug曾 several hundred subjects received the same batch of vaccine no other case of abscess occurred. Tw ampoules of this batch with their diluting fluid were received from Lagos and were cultured on Lowen. stein medium; they grew only B.C.G. Enquiries the chest clinic where the second patient had bee inoculated revealed that three other patients hagl been injected with the same batch of vaccine withoyt experiencing any complication.

Myco. fortuitum is known to be widely distri. buted in nature. Apart from its occurrence in lesions of man and cattle it has been found in fish, watef and soil (Gordon and Smith, 1955). It is therefots quite possible that these infections were due to contamination of the syringes or their contents wit this ubiquitous organism. It is also conceivable the it was present on the patient's skin before the iff jection and that it was introduced into the tissues by the needle prick.

I am indebted to Dr. J. S. Crowther, Dr. G. Shneerso and Dr. Vernon Davies for clinical details of their patients, to my former colleague Dr. E. Hardy for the 
culture of patient R.W.; to Professor I. Friedmann for sections of the inner ear of mice and for their interpretation; to Dr. Ruth Gordon, of Rutgers, The State University, New Brunswick, for confirmation of the diagnosis of the three cultures; to Dr. V. A. Hetreed, of the Tuberculosis Survey, Lagos, for information and supply of ampoules of the batch of B.C.G. used on patient C.U., and to Mr. B. L. Mepham for the photographs.

\section{REFERENCES}

Beck, A. (1959). J. Path. Bact., 77, 615.

Bönicke, R. (1962). Bull. int. Un. Tuberc., 32, 13.

Corpe, R. F., Smith, C. E., and Stergus, I. (1961). J. Amer. med. Ass., $177,262$.

Costa Cruz, J. da (1938). Acta Med. Rio de Janeiro, 1, 297.

Dross, I. C., Abbatiello, A. A., Jenney, F. S., and Cohen, A. C. (1964) Amer. Rev. resp. Dis., 89, 923.

Findlay, G. M., Klieneberger, E., MacCallum, F. O., and Mackenzie, R. D. (1938). Lancet, 2, 1511.
Forbes, G. B., and Strange, F. G. St. C. (1949). Ibid., 1, 478.

Gordon, R. E., and Mihm, J. M. (1959). J. gen. Microbiol., 21, 736. - and Smith, M. M. (1953). J. Bact., 66, 41. (1955). Ibid., 69, 502.

Gorrill, R. H. (1952). J. Path. Bact., 64, 857.

- (1956). Ibid., 71, 353.

Hartwig, E. C., Cacciatore, R., and Dunbar, F. P. (1962). Amer. Rev. resp. Dis., 85,84

Konno, K. (1960). Ibid., 82, 422.

Kushner, D. S., McMillan, S., and Sanderi, M. (1957). Amer. Rev. Tuberc. 76, 108

Levaditi, C., Vaisman, A., and Levy, P. (1949). Presse méd., 57, 852.

Limbos, P., Bretey, J., Jadin, J., and Brutsaert, P. (1961). Ann. Soc. belge Méd. trop., 2, 127.

Medveczky, E. (1960). Amer. Rev. resp. Dis., 81, 757.

Penso, G., Castelnuovo, G., Gaudiano, A., Princivalle, M., Vella, L., and Zampieri, A. (1952). R. C. Ist. sup. Sanità, 15, 941.

Sabin, A. B. (1938). Science, 88, 189.

Therapeutic Substances Regulations (1952). No. 1937, p. 17

Vandepitte, J., Desmyter, J., Brochier, J., and Gatti, F. (1962) Ann. Soc. belge. Méd. trop., 42, 558.

Wells, A. Q., Agius, E., and Smith, N. (1955). Amer. Rev. Tuberc., $72,53$. 